The Philosophical Journal of Conflict and Violence

Vol. II, Issue 2/2018

(C) The Authors 2018

Available online at http://trivent-publishing.eu/

\title{
Violence Among Beasts. Why is it Wrong to Harm Nonhuman Animals in the Context of a Game
}

\author{
S.P. Morris \\ Associate Clinical Professor of Sport Leadership \& Management \\ (Miami University, Oxford, Ohio), USA, morrissp@miamioh.edu
}

\begin{abstract}
The thesis of this paper is that games and sports that harm nonhuman animals are unethical because they exceed the permissible limits of optional harm and the more harm the game imposes on the nonhuman animal(s) it objectifies the worse the ethical transgression. Factors in the analysis include the nature of games and sports, the ontology of beings (i.e., human and nonbuman animals) in games, the mitigating power of informed consent among buman game-players and its absence among nonhuman game players, harm, and intent.
\end{abstract}

Keywords: Animals ; Ethics ; Games ; Sports ; Violence.

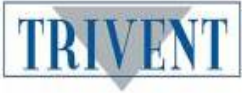

The PJCV Journal is published by Trivent Publishing.

This is an Open Access article distributed in accordance with the Creative Commons Attribution Non Commercial (CC-BY-NC-ND 4.0) license, which permits others to copy or share the article, provided original work is properly cited and that this is not done for commercial purposes. Users may not remix, transform, or build upon the material and may not distribute the modified material (http:/ / creativecommons.org/ licenses/by-nc/4.0/) 


\title{
Violence among Beasts. Why is it Wrong to Harm Nonhuman Animals in the Context of a Game
}

\author{
S.P. Morris \\ Associate Clinical Professor of Sport Leadership \& Management \\ (Miami University, Oxford, Ohio), USA, morrissp@miamioh.edu
}

\begin{abstract}
The thesis of this paper is that games and sports that harm nonhuman animals are unethical because they exceed the permissible limits of optional harm and the more harm the game imposes on the nonhuman animal(s) it objectifies the worse the ethical transgression. Factors in the analysis include the nature of games and sports, the ontology of beings (i.e., human and nonhuman animals) in games, the mitigating power of informed consent among buman game-players and its absence among nonbuman game players, harm, and intent.
\end{abstract}

Keywords: Animals; Ethics; Games; Sports; Violence.

"If the hope of slaughter and the expectation of tearing in pieces the beast doth please thee, thou shouldst rather be moved with pity to see a silly innocent hare murdered of a dog: the weak of the stronger, the fearful of the fierce, the innocent of the cruel and unmerciful... count hunting the lowest, the vilest, and most abject part of butchery... the hunter seeketh nothing but pleasure of the silly and woeful beasts' slaughter and murder."1

Thomas More

\section{Introduction}

The words of Thomas More, though extracted from the context of Utopia, are remarkable for their place in history. More published these words in the year 1516. By postEnlightenment standards the world of the early $16^{\text {th }}$ century was a horrifically violent place, as Steven Pinker has thoroughly documented in his book The Better Angels of Our Nature: Why Violence Has Declined ${ }^{2}$. That More would think carefully about violence beyond his conspecifics, in his era, is fairly remarkable, though he is surely not alone in that regard. Our better angels have enabled us to tame so much of our inner demons, our violent potential, and our impulses for the worst. So much of human savagery has been relegated to history, a heuristic, museum exhibits: vestiges. Of course, this is not fully so. These pieces are still in us. We are and perhaps always will be capable of great violence.

One important realm of humanity in which we have not squeezed out violence is in the special meta-reality of games, a second world of unreal problems that we have fabricated as

\footnotetext{
1 Thomas, More, Utopia, trans. Ralph Robinson (London: Blackie and Son, 1908), 135-136.

2 Steven Pinker, The Better Angels of Our Nature: Why Violence Has Declined (New York: Penguin Books, 2011).
} 
a plaything. ${ }^{3}$ When we think of violence in games and sports I imagine the majority of us conjure images of boxers and rugby players, ice-hockey goons and American footballers, but my focus is in quite a different place. My focus is on a place often darker, bloodier, and deadlier: a place where pain and suffering howl not because a howl is more base but because it cannot be spoken. I am interested in violence among beasts.

I am taking liberty with the word beasts that necessitates some explanation. Of course, there are many definitions of the word, but I have two in mind that I am deliberately conflating to make a rhetorical point. In one sense a beast is "an animal, especially a large or dangerous... one" and in another sense a beast is "a person's brutish or untamed characteristics"4. I intend to draw these two together here because there is a subspecies of games and sports wherein humans make violent use of animals more or less as objects and such instances lay bare an ethical short-circuit in our human brains that calls back our inner beastliness in an ethically tawdry and broken way. Violence and all of the havoc and harm that it wreaks may be endemic in the animal world but to gratuitously add to it for the sake of games and sports is, plain and simple, unethical. This is my thesis: Games and sports that harm nonbuman animals are unethical because they exceed the permissible limits of optional harm and the more harm the game imposes on the nonbuman animal(s) it objectifies the worse the ethical transgression.

There are differences in degree. Correlations exist between the complexity of animal minds (human and nonhuman) such that as complexity increases so does the breadth and depth of potential harm; there are more and worse ways to harm beings higher on the phylogenic ladder. This is my bare bones thesis; here is the flesh.

\section{Human Creativity, Good and Bad}

Human brains are the infrastructure of our better angels. Our brains-networks of powerful human brains-enable us to pacify, civilize, and humanize. ${ }^{5}$ But they are like a double-edged sword. We can conjure elaborate modes of destruction more easily than we can peace treatises. The various instruments and methods of warfare or torture that we have brought to the world illustrate my point here. We have shown a macabre creativity at various places and times in human history, thanks in some part to our powerful and creative brains. Yet the modern world is a relatively peaceable place. In many contexts it is even opulent.

This is much less true beyond our conspecifics. Nonhuman animals do not have the power-of-mind that we do, nor the benefit of networking them to the degrees that we can. There is a continuum of difference, of course, but the human capacity to think and reason, both individually and collectively, appears unparalleled in our known universe. Nonhuman animals seem nowhere near organizing themselves in peaceable ways to resolve conflicts over territory, social hierarchy, food, procreation, and the presumed disagreements among foxes and hares regarding what the former should eat, for example. This is true at least in comparison to the complex systems of societies, agreements (e.g., conventions and laws), and enforcement mechanisms that we have built; the Leviathan that Thomas Hobbes described in the mid- $17^{\text {th }}$ century ${ }^{6}$. Because human and nonhuman animal minds are different our ethical standards are different. Specifically, human minds enable us to create them whereas nonhuman animals reside in much more of a Hobbesian state of nature.

\footnotetext{
${ }^{3}$ I am working from the assumption that all sports are games and thus throughout this paper my references to games are meant to be inclusive of sports.

${ }^{4}$ Alphabet Inc, Google.com, April 20, 2018. goo.gl/DGRpYX (accessed April 20, 2018).

${ }^{5} \mathrm{I}$ am referring to Steven Pinker here, specifically chapters 2 through 4 and 8 of. The Better Angels of Our Nature: Why Violence Has Declined

${ }^{6}$ Thomas Hobbes, Leviathan (New York: Pearson Longman, 2008).
} 
All of these considerations and differences are quite interesting per se, but the bull's-eye of my attention is a few layers below. In the chasm between human and nonhuman animal minds is just one of the realms in which human ethics are asked to bare weight. ${ }^{7}$ PostEnlightenment prosperity has opened up myriad domains of human creativity and flourishing. So far removed from the state of nature are we humans that we have, for untold millennia now, taken up the practice of deliberately creating new problems for ourselves so that we may experience the delight of solving or attempting to solve them ${ }^{8}$.

\section{Games (and Sports) as a Second, Gratuitous World}

If hundreds of thousands of years of evolution had produced a very clever problem-solving hominid who grew bored in the absence of challenging problems, what better gift could be presented than a playground that is problem based-namely, a game! ... a place in which we humans are importantly and unmistakably unique... other animals live in one world. We live in two. ${ }^{9}$

Games and sports are domains of creativity where we humans flash our relative brilliance. They are an artificial world in which we fabricate from abstraction altogether new challenges for ourselves.

People play games so that they can realize in themselves capacities not realizable (or not readily so) in the pursuit of their ordinary activities... with the invention of games far removed from the pursuits of ordinary life, quite new capacities emerge, and hitherto unknown skills are developed...

People play games not only because ordinary life does not provide enough opportunities for doing such and such, but also (and more interestingly) because ordinary life does not provide any opportunities at all for doing such and such...

Games are new things to do, and they are new things to do because they require the overcoming of (by ordinary standards) unnecessary obstacles, and in ordinary life an unnecessary obstacle is simply a contradiction. ${ }^{10}$

The front edge of our powerful minds can build this sort of second world wherein we enjoy the Aristotelian Principle described by John Rawls: a "desire for variety and novelty... ingenuity and invention... anticipation and surprise... [wherein] the form of the activity, its structural development, is fascinating and beautiful"11. Living in the second world of games

\footnotetext{
${ }^{7}$ Frans de Waal is well known for his comparative ethological work on minds, including some works that broach ethics. See Sarah Brosnan \& Frans de Waal, "Fairness in Animals: Where to From Here?," Social Justice Research 25/ 3 (2012): 336-351. From Frans de Waal see also "Anthropomorphism and Anthropodenial: Consistency in Our Thinking about Humans and Other Animals," Philosophical Topics 27/ 1 (1999): 255-280; Are We Smart Enough to Know How Smart Animals Are? (New York: W.W. Norton \& Company, 2016). Gary Steiner's Animals and the Moral Community: Mental Life, Moral Status, and Kinship (New York: Columbia University Press, 2008) is also a good, brief yet broad review of the scientific and moral differences between human and nonhuman animal minds.

${ }^{8}$ R. Scott Kretchmar, "The Normative Heights and Depths of Play," Journal of the Philosophy of Sport 35 (2007): 1-12.

${ }^{9}$ Ibid., 8.

${ }^{10}$ Bernard Suits, "The Elements of Sport," in Ethics in Sports, ed. William J Morgan (Champaign, IL: Human Kinetics, 2007), 14-15.

11John Rawls, A Theory of Justice (Cambridge, MA: Harvard University Press, 1999), 375.
} 
requires a "gratuitous logic" with which we enter a sort of simulacrum ${ }^{12}$. A game is a mixed or quasi-reality that we enter into just a level above, but still in touch with what we take to be reality. Take the game of golf, for example. By ordinary first-world standards, golf is patently absurd. "Watch what I can do," says the dedicated golfer to a disinterested friend before striking a 9-iron; to which the obviously unimpressed companion replies: "So what?" Such discordance would be owed entirely to context. From the companion's first-world perspective clubbing dimpled spheres toward a series of holes in the ground might go so far as to raise concern about the golfer's well-being. But the golfer has two vantage points from which to view the act. The game player can see the absurdity as easily as anyone else, but they can also see the beauty of a contrived problem and what it is really getting at, which is an extra opportunity to pursue excellence; again, a second world, layered onto reality ${ }^{13}$. Games are a supra-reality. This is a slightly re-conceptualized framing of the gratuitous logic that they require. Games are something extra. They are not necessary, and our gratuitous logic toward them recognizes this fact and how central it is to account for their potential value.

\section{Nonhuman Animals in the Second World}

Some of the games we create include all of the majesty of the Aristotelian Principle and map onto "an explanatory hierarchy" such that their complexity adds to the achievements that we wring out of them, and yet they are nothing short of brutal ${ }^{14}$. This is the longer way of saying that some of our games are ghastly violent.

Humans fell a raging bull by repeatedly stabbing it in the back until it asphyxiates in its own blood or has sufficient spinal cord damage to cease vital body systems: bull fighting. Humans launch edged metallic projectiles at unsuspecting animals in hopes of ripping open their lungs, hearts, spines, or other vital tissues, bringing the beast to death: hunting ${ }^{15}$. Humans tether animals with mechanized teeth that take steadfast bite of roaming feet, legs, and heads and then pry the beast loose, before or after impalement or crushing its throat: trapping. Humans lure various makes of sea-dweller into taking barbed hooks into their mouths, whereupon the hooks are ripped into flesh and they are dragged and drowned if not first butchered alive: fishing. Humans stoke beasts to fury and place them together in confinement in order to battle, tooth and claw, to death: pit-fighting. Humans train beasts to run themselves ragged and employ perverse pharmacology to extract speed, endurance, and tolerance for extremes of pain and suffering and then dispatch with the exhausted creatures through rudimentary modes of slaughter: horse and dog racing ${ }^{16}$. This could easily go on.

12 William J. Morgan, Leftist Theories of Sport: A Critique and Reconstruction (Chicago, IL: University of Illinois Press, 1994), 211.

${ }_{13}$ Bernard Suits, The Grasshopper: Games, Life, and Utopia, $3^{\text {rd }}$ ed. (Peterborough, Ontario: Broadview Press, 2014).

${ }^{14}$ Thomas Hurka \& John Tasioulas, "Games and the Good," Proceedings of the Aristotelian Society 106/ 1 (2006): 222.

${ }^{15}$ See S.P. Morris, “The Sport Status of Hunting.” International Journal of Applied Pbilosopby 28/ 2 (2014): $391-407$.

${ }^{16}$ See National Public Radio,"Musher Mutiny, Dog Doping: Scandals Mire The Super Bowl Of Sled Dog Races" (March 3, 2018), https://www.npr.org/2018/03/03/590089289/musher-mutiny-dogdoping-scandals-mire-the-super-bowl-of-sled-dog-races (accessed April 1, 2018). See also The New York Times, "Mangled Horses, Maimed Jockeys" (March 24, 2012), https://www.nytimes.com/2012/03/25/us/death-and-disarray-at-americas-racetracks.html (accessed November 13, 2017). 
This is a truncated list made only to put color to my point, which is that we have a long and storied history of harming, even brutalizing and killing nonhuman animals for the sake of games. I recognize that I am papering over vastly different practices here and that there is nuance, diversity, and complexity in each respective context (When is this not true?). I am moving quickly despite the hazards of doing so because it is too easy to find examples of these practices that showcase their barbarism. To be more direct, these practices and their variants are games that humans have made of harming animals and in many cases they involve extreme violence, pain, suffering, harm, and death. This lot of factors varies in degree depending on the nature of the game and the animal that it makes its object. This is why I made it a point to include practices that involve mammals, birds, fish, and possibly other classes among the animal kingdom. These differences matter in our relative assessments of pain, suffering, harm, and death, but as I argue later, they matter mostly in determining how bad a given game is, rather than whether it is bad.

\section{Minds and their Abilities to Consent}

This variance across classes reconnects with my earlier comments about our relevant differences with nonhuman animals. The ethical quandaries in the scope of interpersonal violence in game-play are in many ways relevantly different than the ethical issues that crop up when we play games across species. Human intellectualism equips us to consent to interpersonal violence. This is how boxers and mixed-martial artists avoid the iron hand of the Leviathan. This is how pankration ever existed, or American football, or ice hockey, or rugby, or any other such interpersonal sport that ranks somewhere above zero on the continuum of violence. We agree, formally and informally, to waive our usually coveted rights-legal and moral, at least - not to be harmed by others. For centuries we have meticulously crafted and manicured these rights to promote safety, security, protection from our aggressors, and disincentives against our own aggressive potentials, among other things ${ }^{17}$. Then, as an ante to enter the second world, we cast it all aside, even if only for a small window of time, as if it were some piece of soiled clothing. Such a phenomenon (and how phenomenal it is!) is not an ethical desert. There is nuance and complexity in violent interpersonal games and sports, but I will leave it to others to show the trails through that particular ethical landscape ${ }^{18}$. What I am keen to argue is that the ante to drag nonhuman animals into the second world with us is rife with moral oversights, missteps, and mistakes.

None of this rights-suspension business works across species. I should be clear before going further that here I am not necessarily talking about legal rights; though it is also worth pointing out that some nonhuman animals are granted such rights (e.g., animal welfare laws, anti-cruelty laws, et cetera). Rather, I have in mind the less concrete moral rights, which sometimes ground legal rights but more often govern our morality rather than legality. So much of what exempts violent game players from the hard hand of the law is their willingness and ability to consent. The human ability to put our moral and/or legal rights not to be harmed on hold goes a long way, perhaps all the way, toward mitigating ethical concerns about violent interpersonal games and sports. The same cannot be rightly said across species. Nonhuman animals cannot transcend the world in the way that many humans can when they waive their rights, for example. In this way, nonhuman animals are more bound to the first world. They play in the world, but they do not play games ${ }^{19}$. And

\footnotetext{
${ }^{17}$ Steven Pinker, The Better Angels of Our Nature: Why Violence Has Declined.

18 See Robert Simon, "Violence in Sports," in Ethics in Sports, 345 -356. Champaign; Michael Smith, "What is Sports Violence?," in Ibid., 199-216.

${ }^{19}$ R. Scott Kretchmar, "The Normative Heights and Depths of Play" : 1-12.
} 
similarly, they have rights in the first world, but they cannot waive them as an ante to enter the second.

In contrast with all other living beings, the human understanding of the world... is characterized by freedom from the environment... animals can leave their environment and wander the entire earth, but in doing so they cannot break free of their confinement in the environment. For humans, on the other hand, going beyond the environment is a going-beyond toward the world and signifies not an abandonment of the environment but rather a different relationship to it, a free, distanced relation. ${ }^{20}$

The inability of nonhuman animals to put this sort of distance between themselves and the first world explains a lot-perhaps everything-about why we cannot safely assume their consent to join a game that puts them at risk of harm.

There are cases in which it may be reasonable to believe that some nonhuman animals_-specifically the more intellectually sophisticated among them-are capable of some kind of tacit consent. For example, I think we can reasonably defend the belief that a tail-wagging dog who runs to his person with evident exuberance and stretches long and supine is giving something very much like, perhaps even exactly like, tacit consent to a nice belly-rub. I do not think we can categorically say that nonhuman animals are incapable of consent, though much of this claim will hang on the analytic statements that we take to define the concept of consent, so it is, at least to a minimal degree, controversial. On the one hand it seems unlikely that we are to get into moral trouble by assuming consent regarding dog-belly-rubs or cat-head-scratches and the like. Even if we cannot assume that these sorts of animals consent, even tacitly, to these sorts of treatments we would still be left grasping at air to find moral qualms because of the patently harmless nature of the acts; nor does petting one's dog raise the odor of harmless wrongdoing ${ }^{21}$. On the other hand, where we would be likely to find moral hot water is in making assumptions about consent in the context of actions that involve harm.

\section{Harm to Nonhuman Animals in the Second World}

When harm is a factor the differences between human and nonhuman animal minds is such that nonhuman animals cannot be presumed to consent in any meaningful way to enter the second world. Within both the narrower domain of legal rights and the broader domain of moral rights we work from the assumption that we ought to avoid gratuitous harm-e.g., risk, allowing harm, doing harm, intending harm, foreseeing harm, all the lot-and from that assumption we carve-out exemptions like those afforded to pankrationists and pugilists because they consent to the suspension of these protections. ${ }^{22}$ It takes a special kind of consent (i.e., informed consent) to make an ethically defensible accounting of this and it takes a special kind of mind, a relatively sophisticated kind of mind, to navigate this sort of consent.

If we cannot satisfactorily answer the questions about the nature or existence of the consent required, then the carve-out is denied. This is the business of soft paternalism and we exercise it daily in denying our children ice-cream for breakfast, in insisting that we hail a

\footnotetext{
${ }^{20}$ Hans-Georg Gadamer translated in Gary Steiner, Animals and the Moral Community: Mental Life, Moral Status, and Kinship (New York: Columbia University Press, 2008), 9.

${ }^{21}$ Joel Feinberg, Harmless Wrong-doing: The Moral Limits of the Criminal Law (Oxford: Oxford University Press, 1990).

${ }^{22}$ I am relying on Shelly Kagan here, specifically "Doing Harm" in Normative Ethics (Boulder, CO: Westview Press, 1998), 70-105.
} 
ride for one another if we may over-indulge at a cocktail party, or when we make harder choices, like committing to palliative care for our friends and family members as time wanes their autonomy. Consent to harm comes with strings attached; specifically, the capability of mind to give informed consent, at least. This is highly contextual, conditional, temporal, tenuous, and subject to nearly constant scrutiny. This complexity puts it beyond the reach of many human minds and almost certainly beyond the realm of all known nonhuman animal minds. The moral trap springs, then, when we involve nonhuman animals in our games in ways that involve harm because they are incapable of doing what is necessary to lift the ordinary prescription to avoid gratuitous harm; i.e., providing informed consent.

We sometimes fold them into game-play not necessarily against their will but rather without their knowledge of even being in a game. That is to say, we make them objects in our games, and the trouble with this is that they are not merely objects; they are subjects too, and in some ways that make some of them relevantly similar to us. This sort of objectification is the centerline of the pathway to harm. Our failure to properly account for the subject status of nonhuman animals seems to explain a lot about how we can make the moral mistake of harming them in the context of a game. Humans are not the only animals that are the subjects of a life. Many other species also have

Beliefs and desires; perception, memory, and a sense of the future, including their own future; an emotional life together with feelings of pleasure and pain; preference and welfare-interests; the ability to initiate action in pursuit of their desires and goals; a psychophysical identity over time; and an individual welfare in the sense that their experiential life fares well or ill for them, logically independently of their utility for others and logically independently of their being the object of anyone else's interest. ${ }^{23}$

When we objectify animals in the context of games, we erase this reality from our deliberative process and this erasure blows a gaping hole in the explanatory power of our thinking. Josè Ortega y Gasset, who staunchly (and poetically) praises hunting, says: "every good hunter is uneasy in the depths of his conscience when faced with the death he is about to inflict" 24 . In the face of this "unease" he or she reaches for cognitive dissonance-which is the inverse of how we are ordinarily encumbered by it—and finds it through pretending that the animal is so much less a subject of a life than it really is. Once this intellectual sleight-of-hand is achieved the next step is to convert potential to kinetic energy by losing the projectile.

\section{Objectification}

As a possible retort, I would expect that there are many ethical ways to objectify nonhuman animals that are not necessarily malicious or evocative of harm. For example, would it be wrong to examine a dog in search of the Platonic form of a dog? We sometimes objectify humans in a similar way. We examine each other's physique, facial structure, skin tone, teeth, hair texture, the vibrancies of our voices, and even the quality of each other's sex organs! But of course, the intricacies of body image and body politics are flush with ethical problems that are more or less to do with matters of objectifying people in this way. People are so much more than objects and so these practices can make reductionist mistakes, among others. This is not necessarily so with nonhuman animals. It would be hard to miss

23 Tom Regan, The Case for Animal Rights (Berkeley, CA: University of California Press, 2004), 243.

24 Josè Ortega y Gasset, Meditations on Hunting (Belgrade, MT: Wilderness Adventures Press, Inc., 2007), 98. 
the ethical difference between a statement like "that dog is too fat" and "that girl is too fat." The relative complexity of human minds makes the latter a far more dangerous thing to say.

So, it is not enough to say that making animals objects in our games necessitates ethics per se. Like us, they are much more than objects, but they are not as much more subjects as we are. Our ontology as subjects goes so much further than theirs. ${ }^{25}$ Both human and nonhuman animals live as subjects but the relative differences in degree correlate with differences in ethical standards for the respective groups. The degree of ethically tolerable objectification of nonhuman animals would seem to be somewhat greater than however much objectification of our conspecifics we are happy to ethically defend. Objectifying humans is sometimes ethically tolerable under some range of conditions and objectifying nonhuman animals is sometimes ethically tolerable under some (much) wider range of conditions.

Perhaps it is plain to see that this leads to a familiar line-drawing problem. How much objectification of a nonhuman animal is too much, for the sake of a game? The variables that affect our answer(s) to this question abound. What is the animal's ontology? Does it have a mind? What is the nature of its mind? What is its mind capable of? What does the game do to the animal and its mind? Is the animal harmed? How great is the harm? How great is the harm in relation to the benefits taken by the game's player(s)? Is the animal at mere risk of harm? Can subjecting others to elevated risks or harm without their consent be ethically defended in cases where the others are nonhuman animals? ${ }^{26}$

How these questions are rightly answered links back to my earlier comments about nonhuman animals in the second world and the deliberate point that I made to work across classes among the animal kingdom. These questions can only be rightly answered with a full ecological accounting of the differences in ontology across minds. Whatever it is like to be a bat is probably relevantly different than whatever it is like to be a bass ${ }^{27}$. These differences, whatever they are, will serve as multipliers or dividers when we mete out assessments of harm. It seems reasonable that as we slide toward rudimentary on the animal taxonomy the breadth and depth of potential harm will narrow and vice versa. The same act, say, a painful but short death by drowning, would be less harmful to a fish than it would to a chimpanzee because of the relatively more complex welfare and preference interests of the latter. The same sort of multivariate and continuous conceptualization of harm would seem to make all the difference in assessing if and to what degree we harm animals in and for the sake of games and sports.

\section{The Limitedness of Optional Harm and the Influence of Intent}

Notice that none of these questions about risk and harm have to do with prevention cases; i.e., cases in which one party or another will be put at risk of harm or harmed. In prevention cases harm is inescapable. Because a game is a "voluntary attempt to overcome unnecessary obstacles" they can never be an instantiation of a prevention case ${ }^{28}$. The gratuitous nature of games, their second world nature, their analytically voluntary nature, preempts the

\footnotetext{
25 Though he is speaking specifically of primates, Frans de Waal calls this "the iceberg metaphor, according to which there is a vast mass of cognitive, emotional, and behavioral similarities between us and our primate kin". He extends the metaphor beyond primates throughout Are We Smart Enough to Know How Smart Animals Are. Also see de Waal's "Anthropomorphism and Anthropodenial: Consistency in Our Thinking about Humans and Other Animals" : 255-280.

${ }^{26} J a s o n$ Kawall offers a strong argument for a negative answer to this question (2000). See "Is (Merely) Stalking Sentient Animals Morally Wrong?," Journal of Applied Philosophy 17/ 2 (2000): 195-204.

${ }^{27}$ Thomas Nagel, "What Is It Like to Be a Bat?," The Philosophical Review 83/4 (1974): 435-450.

28 Bernard Suits, The Grasshopper: Games, Life, and Utopia, 43.
} 
possibility of a prevention case because game players will always have the option of returning to their first world. It is a bit amusing that the nasty pejorative that our sporting cultures have attached to this escape hatch is a four-letter word: quit. Of all the vulgarities athletes and game-players shuffle back and forth quit is the one with the sharpest edges. It can never be reasonable for a game-player to say something thing like "I had no choice but to harm" in the context of a game. What a game is makes this impossible. Always, at the decisive moment of a game wherein the player must decide between harm and no harm is the option to quit. Thus harm, in the context of a game, is always optional.

The ethical relevance of this should be hard to miss. When two hockey players drop their gloves and take up pugilism, they are exercising an option in the context of a game and that option involves violence, risk, and potential harm to self or others (likely among other things). To iterate, their minds enable them to navigate the complexities of consenting to violence and remain within or without reasonable reach of the realm of ethically tolerable behavior. They have many options, including the option to play or not play hockey and the option to fight or not fight in the context of hockey. In the ordinary world, our first world, our choices involving risk and harm (among other things) are constrained by our ethics and laws such that "options to do harm will be quite weak and limited" 29.

For example, when I arrive at the last cup of coffee in the pot ahead of my coworker, I have choices. I can start another pot, I can take the last cup and bid her adieu, I can offer her the last of it, or we can share what is left. These options involve only very low-level harm: we both get as much coffee as we desire but at some cost of time, or one or both of us gets less coffee than we desire. Each option involves a setback to our respective interests. That is, harm (at a very low level). This is the kind of "weak and limited" optionality that our ethics tend to permit, relative to harm. Few would think of me as an ethical monster if I politely exhausted the java, I think, and most would consider it a courtesy to choose another option; what philosophical minds might call supererogatory but what we ordinarily think of as "nice."

If the human inclusions of nonhuman animals in the second world were something like the coffeepot politics just described, then there would be so much less to say about the ethics of these practices. But so often this is very far from the case. Options to harm in the first world work at or near this level of harm. The much higher levels of harm that we see in the second world, the world of games, are permissible as options because of the complex negotiations between our (mostly) autonomous human brains. We choose to enter the second world and, to the extent that we give informed consent, we know what this means relative to harm. Because games are entirely voluntary, harming animals in their context is an instance of optional harm. The ethical line should be drawn where the degree of harm that the animal is subjected to rises above a reasonable interpretation of something miniscule.

One further factor should be addressed: intention, which factors into this analysis in at least two ways. First, we might wonder how unintended harm influences our considerations. Some of the games we have concocted are a bit quirky or eccentric. Dog agilities provoked this thought. If a man competes with a dog to run obstacle courses, he subjects the dog to elevated risk, which could eventuate in harm, which could be fairly high-level. Suppose, for example, that the dog suffers a painful injury such as a broken leg or dislocated hip or slipped vertebra. Suppose that the injury results in chronic pain. Would this type of practice exceed what is permissible as optional harm or would the accidental nature of the harm-its unintended nature-be enough of a discount to stay within the realm of ethically permissible optional harm? Probabilities seem to point to the answer. How likely would such harm be? And what is the differential probability of that kind of harm? In other words,

${ }^{29}$ Shelly Kagan, Normative Ethics, 169. 
how much more risk would dog agilities be to the dog than an ordinary, non-dog-agility-day in the life of a dog? The reason for raising these questions is to point to the gray areas along the continuum of harm to nonhuman animals in the context of games. That is, to explicitly acknowledge that there is gray.

As for the second way in which intention factors into this analysis: what is not gray-at all-is a kind of consequentialist move to defend harming nonhuman animals for the sake of a game by pointing to the differential pleasures that might be cashed out of the game by its human players. For example, a hunter may love to hunt. Hunting, at its best, may score on a fairly high order of the explanatory hierarchy. It can be a very rich and valuable game to the bunter ${ }^{30}$. But the hunter's intent is unmistakable. The hunter's intent is to harm the animal-mortally_and some non-zero percentage of the pleasure wrung from the act is attributable to this fact. I feel safe in this assumption because the hunter's highest preference is usually to have his or her intentions actualized, which is the same thing as bringing mortal harm to the subject of the hunt. Even accepting that his or her means are highly particular, what the hunter idealizes is the destruction of the animal. The hunter is pleased to have done harm. This is not a compliment.

Activities differ in degrees of decency and badness, and some are choiceworthy, some to be avoided... pleasure proper to an excellent activity is decent, and the one proper to a base activity is vicious... appetites for shameful things are blameworthy. ${ }^{31}$

More generally, games that involve the intent to harm nonhuman animals score so much worse for this factor. That the harm in these sorts of games is intentional mars them, ethically.

\section{Conclusion}

Games and sports are a second world. They are a playground of imagined problems, layered onto the first world. To be a player of them we must assume a gratuitous logic, which is an acknowledgement of the fact that they are unnecessary. Many of our games are violent and their violence cascades into pain, suffering, harm, and even death. Nonetheless we are happy to take them up and supply wholehearted ethical cover for them. Our most reliable instrument for doing so is our high order intellect, which allows us to articulate and practice abstract concepts like informed consent. However, some humans are not capable of this and it is reasonable to believe that virtually no nonhuman animals are. Without this intellectualized agreement our ordinary moral (and sometimes legal) obligations to avoid gratuitous harm remain as an ethical redline. If we harm others without their consent and the harm involved exceeds the low-order sorts that we generally defend as ethically permissible options, then our actions are unethical. Because our games are by their very nature wholly voluntary, they cannot be instances of unavoidable harm. Their gratuitous nature means that any harm that they might entail must be optional. This fact, combined with our ethical prescriptions to avoid gratuitous harm and the limits that we generally place on optional harm limits our ability to bring animals into the second world with us, ethically.

\footnotetext{
30 See S P Morris, "Challenging the Values of Hunting: Fair Chase, Game Playing, and Intrinsic Value," Environmental Ethics 35 (2013): 295-311.

${ }^{31}$ Aristotle, Nicomachean Ethics, trans. Terence Irwin (Indianapolis, IN: Hackett publishing Company, Inc., 1999), 1175b, 25-30.
} 
Games and sports that harm nonbuman animals are unethical because they exceed the permissible limits of optional harm and the more harm the game imposes on the nonbuman animal(s) it objectifies the worse the ethical transgression.

Omitted from my analysis (for the sake of brevity) is a consideration of our indirect uses of animals in games. For example, our games sometimes affect geography in ways that harm nonhuman animals. Think of golf courses and ski slopes as paradigmatic cases. We also manufacture a small proportion of the tools we use in games from materials that affect animals in sometimes-harmful ways. In some cases, this is done in a way that is a middle ground between direct and indirect use. In this case think of the various instruments of our games that we make of animals (e.g., all things made of animal skin). How athletes fuel their bodies necessitates careful ethics as well. In most cases our food choices involve options, which means that ethical prescriptions to avoid gratuitous harm would apply to them too. The foundation of my ethical argument has a scope much broader than what I have considered above. I am well aware of this broader scope and the implications of my argument for our conduct in it.

\section{References}

Alphabet Inc. Google.com. April 20, 2018. goo.gl/DGRpYX (accessed April 20, 2018). Aristotle. Nicomachean Ethics. Translated by Terence Irwin. Indianapolis, IN: Hackett publishing Company, Inc., 1999.

Brosnan, Sarah, de Wall, Frans. "Fairness in Animals: Where to From Here?" Social Justice Research 25/ 3 (2012): 336-351.

de Waal, Frans. «Anthropomorphism and Anthropodenial: Consistency in Our Thinking about Humans and Other Animals. » Pbilosopbical Topics 27/ 1 (1999): 255 - 280. Are We Smart Enough to Know How Smart Animals Are? New York: W.W. Norton \& Company, 2016.

Feinberg, Joel. Harmless Wrong-doing: The Moral Limits of the Criminal Law. Oxford: Oxford University Press, 1990.

Hobbes, Thomas. Leviathan. New York: Pearson Longman, 2008.

Hurka, Thomas, and John Tasioulas. "Games and the Good." Proceedings of the Aristotelian Society 106/ 1 (2006): 217-235.

Kagan, Shelly. Normative Ethics. Boulder, CO: Westview Press, 1998.

Kawall, Jason. "Is (Merely) Stalking Sentient Animals Morally Wrong?" Journal of Applied Philosophy 17/ 2 (2000): 195-204.

Kretchmar, R Scott. "The Normative Heights and Depths of Play." Journal of the Philosophy of Sport 35 (2007): 1-12.

More, Thomas. Utopia. Translated by Ralph Robinson. London: Blackie and Son, 1908.

Morgan, William J. Leftist Theories of Sport: A Critique and Reconstruction. Chicago, IL: University of Illinois Press, 1994.

Morris, S P. "Challenging the Values of Hunting: Fair Chase, Game Playing, and Intrinsic Value." Environmental Ethics 35 (2013): 295-311.

. "The Sport Status of Hunting." International Journal of Applied Pbilosopby 28, no. 2 (2014): 391-407.

Nagel, Thomas. "What Is It Like to Be a Bat?" The Philosophical Review 83/4 (1974): 435-450.

National Public Radio. "Musher Mutiny, Dog Doping: Scandals Mire The Super Bowl Of Sled Dog Races”. March 3, 2018. https://www.npr.org/2018/03/03/590089289/musher-mutiny-dog-doping-scandalsmire-the-super-bowl-of-sled-dog-races (accessed April 1, 2018). 
Ortega y Gasset, Josè. Meditations on Hunting. Belgrade, MT: Wilderness Adventures Press, Inc., 2007.

Pinker, Steven. The Better Angels of Our Nature: Why Violence Has Declined. New York: Penguin Books, 2011.

Rawls, John. A Theory of Justice. Cambridge, MA: Harvard University Press, 1999.

Regan, Tom. The Case for Animal Rights. Berkeley, CA: University of California Press, 2004.

Steiner, Gary. Animals and the Moral Community: Mental Life, Moral Status, and Kinship. New York: Columbia University Press, 2008.

Simon, Robert. "Violence in Sports." In Ethics in Sports, ed. William J Morgan, Klaus V Meier, and Angela J Schneider, 345-356. Champaign, IL: Human Kinetics, 2001.

Smith, Michael. "What is Sports Violence?” In Ethics in Sports: An Anthology, ed. Jan Boxill, 199-216. Malden, MA: Blackwell, 2003.

Suits, Bernard. “The Elements of Sport.” In Ethics in Sports, ed. William J Morgan, 9-19. Champaign, IL: Human Kinetics, 2007.

The Grasshopper: Games, Life, and Utopia. 3rd Edition. Peterborough, Ontario: Broadview Press, 2014.

The New York Times. “Mangled Horses, Maimed Jockeys.” March 24, 2012. https://www.nytimes.com/2012/03/25/us/death-and-disarray-at-americasracetracks.html (accessed November 13, 2017). 